\title{
Marginalizing the Matriarchal, Minority Subject: \\ A Critical Analysis of Human Rights and Women's Reform Projects in Colonial and Postcolonial India through the Case-Study of the 'Mahari-Devadasi'
}

\author{
Shriya Patnaik ${ }^{\mathrm{i}}$
}

\section{Abstract}

This paper focuses on the rights of gendered minorities in India, using the case-study of the matriarchal community of Mahari-Devadasis (temple-dancers in the Jagannath Temple of Orissa, the creators of the classical dance-form Odissi, whose kinship structures, quotidian cultures and religious practices entailed being wed to Hindu deities over mortals). Under the colonial disciplining of deviant sexualities together with racialized bio-politics across the British Empire, they were conceptualized, categorized, and criminalized as "religious prostitutes" under Contagious Disease and Prostitution regulations, from the nineteenth century onwards. However, the abolition of this matrilineal tradition, instead of improving women's life circumstances, propelled a turn towards clandestine networks of sex-work owing to their growing socio-economic stigmatization in the modern Indian nation-state. In problematizing human rights discourses surrounding this now-extinct community in postcolonial India, my research delineates how legal statutes on Devadasi Abolition silenced minority voices by distorting the complex relationship between bodily agency, informal economies of sexual commerce, and women's socio-economic autonomy. The demise of this localized tradition, however, was accompanied with shifts in collective memory and societal perceptions, particularly with respect to their contribution to performative culture within the regional register of Orissa, which this study encapsulates. The paper therein examines social and cultural borders through the lens of globalized cultural flows and grassroots humanitarian movements, especially in the context of such marginalized gendered minorities in South Asia. It methodologically engages with diverse sources, including colonial period archival records, ethnographic fieldwork, parliamentary debates, national women's rights paradigms on prostitution and trafficking, oral histories dealing with the experiential domain of such disenfranchised actors, grassroots level social activist movement advocating for the inclusion of minority subjects into civil society, along with visual culture depicting the Mahari-Devadasi dance-form on global theatrical spaces. It conclusively underscores the role of social activist

\footnotetext{
${ }^{\mathrm{i}}$ Shriya Patnaik is a PhD Candidate in International History, Graduate Institute of International and Development Studies, Geneva (Swiss Government Excellence Scholar).
} 
movements from civil society towards incorporating indigenous struggles within the ambit of global humanitarian paradigms. Through the above factors, the paper elucidates how such grassroots level feminist movements epitomize important catalysts of social change, which challenge mainstream nationalist narratives on human rights. This research thereby posits the need to recuperate such subaltern voices from the marginalia in writing transnational historiographies on gender, sexuality, and human rights.

Keywords: Gender Rights, minorities, socio-cultural border, indigenous populations, social activism, feminist movements, subaltern voices, Mahari-Devadasi, oral histories

\section{Introduction and Background to the Topic}

The courtesans or dancing-girls attached to each temple are called deva-dasis (servants or slaves of the gods). Every temple of any importance has in its service a band of eight, twelve, or more. Their official duties consist in dancing and singing within the temple twice a day, morning, and evening, and also at all public ceremonies. The first they execute with sufficient grace, although their attitudes are lascivious and their gestures indecorous. As regards their singing, it is almost always confined to obscene verses describing some licentious episode in the history of their gods. Their duties, however, are not confined to religious ceremonies. Ordinary politeness (and this is one of the characteristic features of Hindu morality) requires that when persons of any distinction make formal visits to each other they must be accompanied by a certain number of these courtesans. To dispense with them would show a want of respect towards the persons visited, whether the visit was one of duty or of politeness. These women are also present at marriages and other solemn family meetings. All the time which they have to spare in the intervals of the various ceremonies is devoted to infinitely more shameful practices; and it is not an uncommon thing to see even sacred temples converted into mere brothels. They are brought up in this shameful licentiousness from infancy, and are recruited from various castes, some among them belonging to respectable families... The courtesans are the only women in India who enjoy the privilege of learning to read, to dance, and to sing. A well-bred and respectable woman would for this reason blush to acquire any one of these accomplishments. The deva-dasis receive a fixed salary for the religious duties which they perform; but as the amount is small 
they supplement it by selling their favours in as profitable a manner as possible. In the attainment of this object they are probably more skilful than similar women in other countries.

Dubois' perspectives are important as they are representative of orientalist depictions on Devadasi dedication, along paradigms of sexual deviance and moral debauchery, which do not adequately encapsulate this matriarchal community's status historically in terms of their cultural capital or socio-economic autonomy. This paper problematizes such orientalist depictions of Devadasis in the colonial period, under which Devadasi women were erroneously depicted along lines of religious prostitution, superstition, backwardness, and primitiveness, deemed intrinsic to Hindu religion and culture. Such Eurocentric representations helped cement colonial civilizational supremacy arguments and humanitarian interventions across the British Empire and subsequently South Asian nation-states, which manifested along lines of exclusionary women's reform efforts.

To further elaborate, before British annexation of India, temple-dancers also known as Devadasis, inhabited, and performed religious services in Indian temples. They were socially not bound to the institution of marriage in being wed to Hindu gods. They formed local communities known by different names in different areas: for example, Maharis in Orissa, Jogatis or Basavis in Karnataka, Theravardiyars in Tamil Nadu, Natis in Assam, Matangis or Muralis in Maharashtra, Bhavins or Kalavants in the Konkan region, and Bogams in Andhra Pradesh. In their matrilineal kinship structures, these women were not married to mortals but dedicated in temples. They were the creators of Indian classical dance-forms like Bharatnatyam, Odissi and Kuchipudi (Patil, 1975). ${ }^{2}$ Their practices of religiosity and quotidian cultures varied across regions.

In particular, Devadasis in the Jagannath Temple of Orissa ${ }^{\text {ii }}$, also known as Maharis, intrinsically differed in their ritualistic traditions, socio-cultural customs, and kinship ties from other regional variants of temple-dancer communities. Unlike parts of Southern and Western India, where historical evidence alludes to trafficking and coerced prostitution from certain

\footnotetext{
ii Though a contemporary reading of the region reads as 'Odisha', for the purposes of historical consistency, I refer to it as 'Orissa' in this paper.
} 
poor, lower-caste families using the rhetoric of religion, Maharis were respected cultural figures who enjoyed religious and royal patronage and were the historical creators of the classical dance-form, Odissi (Dās, 1925). ${ }^{3}$ As they were not bound by domesticity and conjugal matrimony, some women had royal patrons who paid them for sexual transactions. However, their social status was not defined as commercial sex-workers, but cultural actors as female priests, dance-teachers, musicians, and courtesans. They received a regular maintenance allowance from temple funds and held ancestral properties in Orissa, which were later appropriated into the landed estates of the colonial state. As their matriarchal system mandated a Devadasi's property to be inherited by a biological or adopted daughter to continue the lineage, these women exercised greater socio-economic autonomy and access to the public sphere, historically denied to most married women in the Indian subcontinent (Levine, 2004). ${ }^{4}$

After the implementation of Sections 372 and 373 of the Indian Penal Code, Contagious Diseases Act and Prevention of Dedication Act in the British Raj, Devadasis were criminalized and prosecuted for prostitution. In the postcolonial era, they remain marginalized as commercialized sex-workers. Colonial legislations homogenously grouped the variegated practices of all temple-dancers across diverse regions of the British Raj, as 'deviant' and 'immoral' (Sreenivas, 2011). ${ }^{5}$ By categorizing variations of temple-dancer communities homogenously as 'The Devadasi System' functioning as 'prostitution with a religious sanction,' colonial regulation failed to take into account the distinct characteristics of the Mahari community in the state of Orissa. The scandal that followed the cleansing of temples across India over the issue of Devadasi-dedication, led to a patriarchal occupation of the Jagannath Temple and the erasure of these women from their historic sites of worship (Marglin, 1995). ${ }^{6}$ Subsequently, The Prevention of Dedication Act (enacted into law on October 9, 1947) in postcolonial India imbibed colonial terminologies and ignored the religious and sociocultural particularities of this group. ${ }^{7}$ Following the abolition of the Devadasi System across British India, Devadasis were forbidden from performing religious service across Hindu temples. Whereas they were previously reputable actors in society, they now transitioned to become marginalized, minority subjects, ostracized and living on the fringes of civil society in the independent nation-state (Chakraborthy, 2000). ${ }^{8}$

This paper traces Mahari social stigmatization and economic impoverishment as a direct byproduct of colonial intervention on gender and religion in Orissa. It problematizes homogenizing taxonomies, as well as arbitrary, non-inclusive policy and social reform efforts 
with respect to the Devadasi question by pointing out a region-specific version of this practice, and its lessons for feminist and subaltern discourse. By looking at the history of this distinctive group of women, we can see how gendered legislation that intended to empower females produced contradictory effects of criminalizing and disenfranchising them. This adds to our understanding of how colonial laws continue to affect legal-political systems and socio-cultural norms in postcolonial India, alongside offers a transnational perspective on historiographies of gender, sexuality, minority rights, and humanitarian interventions. Though Indian independence signals a radical discontinuity in structures of legal-political governance, this case-study elucidates historical continuities via the exclusionary politics of governance citizenship for minority groups. However, in the transition from the colonial to the postcolonial, though the patriarchal framework of Devadasi laws remained intact, popular culture and collective memory about this community has radically changed in the regional context of Orissa. This research thereby attempts to 'provincialize the Eurocentrism' (Chakrabarty, $2000)^{9}$ in human rights discourses in situating the life-stories of these women within global feminist movements.

$* * *$

To understand the socio-cultural processes that characterized the life histories of MahariDevadasis, we need to contextualize their practices of everyday life within its specific cultural contours. King Anantavarman Deva started the project of the Jagannath Temple in the twelfth century. When the temple was built, he commissioned the dancing of women as one of the ceremonial aspects of temple worship. Successively, King Ramachandra in the sixteenth century commissioned grants to Mahari dancers to spread this dance-form across the neighboring regions of Bengal and Bihar. ${ }^{10}$ Singing and dancing performances were an intrinsic part of the religious atmosphere of the temple in its formative years. Until the late $19^{\text {th }}$ century when females were not allowed equal access to sites of worship, song and dance emerged as avenues through which Maharis offered devotional services and accessed the public sphere. These women therein historically enjoyed positions of cultural capital and religious prominence alongside male priests in the temple. Outside the temple, they were social workers and distributed food and clothing to those in need. There are accounts of many girls from elite, reputable families in medieval Orissa who voluntarily embraced the tradition as an honorable profession (Prasad, 1923). ${ }^{11}$

In terms of their sexual economy, the anthropological structure of this community lay outside the confines of conjugal matrimony. Maharis were wed to the deity Jagannath over mortals and 
were supposed to remain celibate for life as per the temple's rules and regulations. However, some of these women exercised relationships with royal patrons and priests, not out of sexual exploitation or prostitution (as represented in colonial records), but towards aspects of human companionship. This was confirmed to in my interview with the last living Mahari Sashimani Devi in 2014, who reiterated that these women did not need to engage in sexual transactions out of an economic need as they were financially compensated for their Seva (ritualistic services) within the political economy of the temple, via allowances, landed estates along with daily food from the Mahaprasad Bhoga (sacred food offerings to the temple deities and devotees), like all of the other thirty sex categories of temple-sebaks (temple-servitors/religious priests in the Jagannath Temple). ${ }^{12}$ Furthermore, Frédérique Apffel-Marglin who is known for her pioneering ethnographic work on Maharis discusses their matrilinear inheritance of their ancestral lands. As the system mandated a Devadasi's property to be inherited by a biological or adopted daughter to continue the lineage, these women exercised greater economic earning capacity and gendered autonomy than most groups of married women in the social landscape of Orissa. They also held vast lands and estates, which were subsequently confiscated into the revenue estates of the modern nation-state (Marglin, 1986). ${ }^{13}$

The role of time becomes important in shaping mutating identities across cultural landscapes, social norms, and knowledge-systems. In terms of historic discontinuities, the passage of Section 372 and 373of the Indian Penal Code (1860) and the Contagious Diseases Act (from 1864 onwards), monolithically grouped the practices of all temple-dancers in the British Raj, as 'deviant' and 'immoral' as 'religious prostitutes', with the practice of the tradition declared as a punishable offense. ${ }^{14}$ In the 'Anti-Nautch Movement', Devadasis were extricated from their historical sites of performativity and instead disenfranchised as 'base sex workers'. The dichotomized representations of the unmarried, sexually active Devadasi, either as a victim of abuse or an immoral profiteer, stripped indigenous women of the autonomy to define their vocational status on their own terms, even when their daily lives contested colonial nomenclatures. The passage of homogenizing, orientalized legislations guiding colonial prostitution reform, also ignored regional pluralisms across temple-dancer communities and differences in their quotidian cultures (Chatterjee, 1993). ${ }^{15}$

However, to continue ceremonies, Gotipuas were employed to carry forth the tradition where they feminized their appearances and coexisted alongside Brahman priests in the altered masculine spaces of temples. While the Mahari (female) tradition was regulated under 
prostitution laws, the Gotipua (male) tradition continued to flourish under colonial law. ${ }^{16}$ Gotipuas were young boys who were recruited prior to the coming puberty; marked by their high-pitched voices and ability to enact certain feminine dance movements. In the colonial period, they were compared to 'Boy Players' who performed in British playhouses like Shakespeare's Globe, when women were outlawed from acting on stage. ${ }^{17}$ This demarcates the mapping of gendered roles from theatrical stages of imperial Britain to the temple-spaces of India.

Subsequently, The Prevention of Dedication Act in independent India in 1947, imbibed colonial nomenclatures in the articulation of a pedagogical ideal for respectable citizenship. Following the abolition of the Devadasi System in nation-wide laws, Maharis were forbidden from performing rituals, alongside extricated from the Jagannath Temple's political economy. Under the colonial disciplining of deviant sexualities, such matriarchal actors were conceptualized, categorized, and criminalized as prostitutes under Contagious Disease and Prostitution regulations. Furthermore, to preserve the reputation of temple-spaces, nationalists appropriated British paradigms, whereby the skewed legacy of imperial norms was normalized, reified, and institutionalized in the making of the postcolonial state. However, the abolition of this tradition, instead of ameliorating women's life circumstances, propelled a turn towards clandestine networks of prostitution owing to their rising socio-economic impoverishment and lack of skill development or adequate employment alternatives. Instead of abetting integration into the market economy, colonial reforms of Prostitution and Contagious Disease ironically propelled a turn towards informal economies of sexual commerce, which perpetuated further ostracism against Devadasis and their children (Levine, 2003, pp. Xv-Xvi). ${ }^{18}$

The Jagannath Temple in Puri (as one of the four Chardhams-Hindu pilgrimage sites) is one of the most revered shrines in the history of Hindu religion. It is marked by phenomenal wealth, global prominence, religious endowments, national and diasporic networks. It has extensive rituals of worship upheld by thirty-six classes of Sebaks (temple-servitors), the Devadasi tradition instituting an integral aspect of temple service historically. Colonial officials classified many such temple rituals as forms of 'idolatry', 'superstition' and 'backwardness' (Ramberg, 2014, pp.16). ${ }^{19}$ In the present times, the Jagannath Temple is administered by a joint committee comprising of the Gajapati royal family, district collector, civil servants and priests, and functions as a giant bureaucracy in itself. The Brahmanical hegemony that characterizes this temple is increasingly apparent today in the daily life of the temple, and in prominent 
religious ceremonies like Rath Yatra (Kulke, 1986, pp.4-7). ${ }^{20}$ The Political Economy of the temple therefore becomes an important site of study through its varying periods of religious and gendered alterations.

Colonial incursions upon the temple-complex were primarily driven by economic factors in accessing the temple's funds and Pilgrim Tax (Cassels, 1988). ${ }^{21}$ In 1806, the Governor General's Council passed a law that authorized British authorities to collect a tax from pilgrims visiting the Jagannath shrine, in return for protection from hostile religious factions along the way. ${ }^{22}$ Company policies were also related to political interests where a Brahmanic dominance would strategically enhance colonial administration in Orissa. In the history of the Jagannath Temple, the Gajapati kings were recognized as Calanti Vishnu (Jagannath's mortal representative) and exercised primary control over the temple's religious, administrative, and financial affairs (Kulke and Dash, 1982, pp.48). ${ }^{23}$ The imperial edifice systematically diminished the monarchy's sovereignty over charges of 'inefficient administration' and 'morally deprave' conduct to gain access to the temple's political economy. ${ }^{24}$

Colonial policy over the Jagannath Temple shifted between dual strategies: The first was one of Non-interference in affairs of Indian religion. This created a codified edifice of Brahmanical hegemony and Sanskritic textual rigidity, which ignored the variegated nature of Hinduism in terms of its oral traditions and fluid ceremonial aspects. The second was one of Expansion in which the practices like that of 'Nautch-girls' had to be reformed in bringing western civilizational order in the passage of prostitution regulation laws.

Under British occupation of Orissa in 1803, the East India Company took over the management of temple and assigned a bureaucratic body to supervise administrative affairs. This produced a direct effect on the social and economic positioning of Maharis. From 1840-1859, a series of allegations were levied against the king for engaging in 'indecent' behavior with nautch-girls. ${ }^{25}$ In 1875, the Bengal Government appointed an English superintendent to oversee internal affairs and codified a set of legal guidelines guiding temple management. ${ }^{26}$ The declining monarchy, which had historically given patronage to Maharis, could no longer provide them with a living allowance, or safeguard their reputation in society. The post-colonial state imbibed from colonial structures and disqualified these women from conducting rituals or accessing temple funds that they had historically been entitled to. Consequently, The Jagannath Temple Administration Act (1956) ascertained the powers of the District Collector in 
supervising the temple budget alongside appointed an auditor to allocate endowments and allowances granted to sebaks. Under this, Maharis were not granted any remuneration or temple lands, thus signifying their exclusion from the political economy of this religious institution. $^{27}$

It is instructive to note that one cannot understand the legal predicament of social norms in contemporary India without a historical analysis of the problem. A mapping of puritanical, heteronormative gendered constructs from the colonial to post-colonial societies, which normalized the patriarchal family unit as the predominant establishment for sexual behaviors, shapes the crux of this argument. The dangers that minorities posed to the national project justified coercive and non-consensual state efforts at bodily disciplining. The correction of women's sexualities thus constituted the epistemological and ontological principle against which hegemonic ideals of the patriarchal nation-state and consequently, respectable citizenship, were constructed (Rao, 2003, pp.10). ${ }^{28}$

\section{The Historical Habitat of Mahari Devadasis}

The term Mahari in Oriya translates into 'Lady of the world'. These women were the only female category of Sebaks (temple-servants) who historically performed religious services in the Jagannath Temple. They received Praapya - a salary from the temple revenue like the other priests for their services. Their responsibilities and allowances in the temple and royal palace are discussed in the Oriya texts like Madala Panji, Deshakhanja and Sebakarmani, which are recognized as the authoritative religious texts in the affairs of the temple (Dash, 2010). ${ }^{29}$ They were known as Calanti Lakshmi that is the living embodiments of the Hindu Goddess Lakshmi in Oriya society and were highly skilled Gaunis (singers) and Nachunis (dancers). Moreover, a part of their cultural capital involved training in the vernacular education. ${ }^{30}$ They did not have the stigma of disreputable prostitution or concubinage attributed to them through various political periods that they came to be associated with following the British annexation of Orissa in 1803. It cannot be denied that certain Maharis maintained relations with patrons. However, this relationship cannot be classified as that of sexual exploitation it precludes an exercising of agency/volition, and also implies an erroneous trafficking and coercion narrative (Marglin, 2011, pp.46). ${ }^{31}$ 
Maharis performed a wide variety of religious duties in the temple, alongside social responsibilities in the royal palace and Puri society. The opening of the temple premises at 5 am every morning required the presence of these women to perform the Sakala Dhupa Aarti (sacred lamp ceremony and singing devotional songs). The Mahaprasad Bhoga (sacred food offerings to the temple deities and devotees) could only be performed after the Mahari ritual dance, which symbolized the blessings of Goddess Lakshmi (Hindu goddess of wealth and consort of God Jagannath). Their attendance was required at the royal palace on birth ceremonies, weddings, thread-ceremonies, and funerals, where they would sing Mangala Gita (auspicious songs). The song and dance ritual were an intrinsic part of religious and social ceremonies at the royal palace, for which they received an allowance from the royal purse. The Puri king Dibya Singh Deb who is the current chairperson of temple's Managing Committee, stated in our conversations that at his royal wedding in 1978, it was tradition for Maharis to cook the Managala-Krutiya Bhoji (sacred feast) to welcome the new queen to the household. ${ }^{32}$

The duties of temple-servants are listed in Rajbhoga Ithihasa, which is recognized as an influential text on the rituals of Jagannath puja. This canon describes the origins of Devadasi services to be an intrinsic part of the daily life and culture of the temple since its inception. The rituals discussed in subsequent lines have been recorded from oral accounts on the observance of religious ceremonies by Puri Pujaris/Pandas (priests) performing these services. ${ }^{33}$ Pandit Rabindranath Pratihari, the Brahman priest who had supervised the daily rituals of Maharis, explained in detail the anthropological structure of this community and their socio-economic positioning in Puri society historically. ${ }^{34}$

Maharis perform their religious duties in turns at the Jagannath Temple. On the day of her Seva (ritual duty), the Devadasi is not supposed to take animal food or be engaged to anyone. On that day, she is to spread a cloth on the floor to sleep and not lie on cots as she does on other days. These women are meticulously trained in song and dance by senior Maharis and can only perform religious rites upon having mastered the arts. Most of them are literate; they speak and dress well. On her allocated Seva day, she is expected to get up early morning, bathe and put on the sacred vermillion on her forehead, wear the saree in the manner of married women, adorn herself with jewels, and be present at the temple door when it is opened to sing Managlam (auspicious prayer songs). She is garlanded by priests and given the Kumbarti (silver pot sacral light). She will pour ghee in it and then take it to the temple kitchen where it will be lit by the temple cook and handed over to her as the divine emissary of the deity. She 
will then take the pot to the inner temple, and the light will be shown to the God by a priest. She will be garlanded and shown other marks of honor. In the same manner, the light will be taken to the presence of other minor deities in the temple. She accompanies the ceremonial procession of Pandas (male priests) in bringing the holy water taken from the tank for the deity's bath. She then blesses the water with the Chamarama (fan). Her duties for the day will extend until midnight when the deities are put to rest in the sleeping chambers. The Devadasi will sing the Gita Govinda (corpus of Hindu devotional songs) at the sleeping chambers of the three central deities - Jagannath, Balabhadra and Subhadra, and then depart home for the night after receiving Mahaprasad. ${ }^{35}$

The Madalapanji and Sebakarmani (authoritative texts on the customs of the Jagannath Temple $)^{36}$ mention song and dance as an efficacious method of devotional worship. On the auspicious role of the Mahari within the temple edifice, these sources further state, "She could be neither a child nor an old woman, nor could she be of wicked or bad character." "Devadasi is equal to Goddess Lakshmi, the wife of Lord Jagannath" (Khera, 1996, pp.44). ${ }^{37}$ These sources explicate how Mahari-Devadasis devotional services were an intrinsic part of the sociocultural landscape of Orissa, along with the elite status that was historically accorded to them. These localized sources further contest dominant state narratives of commercialized prostitution or trafficking that has historically been accorded to analogous matriarchal actors.

It is also significant to note that there were strict rules within the Jagannath Temple's Record of Rights guiding the social conduct of Mahari-Devadasis, as relations with pilgrims to Puri, or outside of the temple's priestly community faced threat of expulsion from the temple in tandem with an exclusion of its political economy. This was confirmed to me in my conversations with Frédérique Apffel-Marglin (who has closely interacted with Maharis through the 1960's and 1970's, along with engaged in an in-depth anthropological study of their rituals of religiosity), as well as in my interviews with Sashimani Devi. Sashimani Devi recounted two such Maharis who were ex-communicated from the temple for exercising relationships with patrons outside of Puri and the priestly edifice. For indeed, laws of purity and auspiciousness were critical to the temple's political economy. (Dumont, 1969). ${ }^{38}$ Such narratives inform a profound change of discourse on female agency. The Mahari, as a living embodiment of the female goddess, thwarts the figure of the victimized, coerced girl in need of 'rescue' and 'protection', and instead emerges as a subject exercising socio-economic autonomy and cultural capital. 


\section{Colonial Debates, Prostitution Regulation and Devadasi Abolition Laws}

This first part of this sub-section deals with the methods and motivations of colonial governments in the social construction of the 'religious prostitute' vis-à-vis the figure of the Devadasi. The second part deals with the effects of colonial discourse in transforming an accomplished cultural figure into a degraded sex-worker upon nationalist imaginary, and its effects upon the religious register of Orissa.

The late nineteenth century witnessed a myriad of militaristic circumstances that led to the colonial state intervening in the disciplining of native women. The issue of the public health of the army in the check of venereal disease was politicized as a rationale for gender reform and social regulation projects. ${ }^{39}$ To fulfill the sexual needs of soldiers in alien lands far from their families in the metropole, the Indian Empire with its abundant reserves for sexual fulfillment, was differentiated from social restraints of domesticity and conjugal matrimony in the metropole where sexual deviance were policed and punished (Hyam, 1990). ${ }^{40}$ However, the rapid outbreak of venereal diseases/sexually transmitted diseases within the military in cantonment areas during the Revolt of 1857 , necessitated the need for the implementation of the Contagious Diseases Act onto India to preserve the public health of the army and racial purity in the Raj.

Reforms on prostitution, concubinage and contagious disease, fitted into a larger pattern of racial and gendered dominance of colonial elites to subjugate non-western populations in mapping mechanisms of social control that had previously been deployed in Britain (Ballhatchet, 1980). ${ }^{41}$ Tropical medicine identified venereal disease as a predominantly oriental crisis contracted through sexual contact with native women, which was pernicious to the constitution and discipline of British troops. In a health memorandum issued to the army in 1905, Commander-in-chief Lord Kitchener posed native women as a group of disease carriers who posed a direct threat of contamination by soliciting military clients (Arnold, 1993, pp.34). ${ }^{42}$ The presumption of affliction in all native women as a 'morally dubious category' led to extensive efforts to cleanse cantonment areas of what was presented as an intrinsic problem of the 'deprave spaces of the orient' (Smith, 1971). ${ }^{43}$ The racialization of contagious disease led to a series of detentions and invasive health examinations for women in cantonment areas, and the imposition of prostitution laws in India that were far more coercive in scope than in Britain (Levine, 1994). ${ }^{44}$ 
The sex-worker therein emerged as a central figure in maintaining a civilizational yardstick of difference between the respectable, western woman from her deprave South Asian counterpart. ${ }^{45}$ However, administrators struggled with the construction of a working definition of prostitution in India. While prostitution was discursively constructed as a cultural phenomenon intrinsic to Indian society, oriental conceptualizations failed to account for pluralistic social relations that evaded a legal definition. The Secretary to the Bengal Presidency noted some of the problems that entailed in prosecuting various groups of unmarried women on Prostitution or Contagious disease related charges:

Officers engaged in working the Act [the Indian Contagious Diseases Act 1868: Act XIV] do constantly feel themselves unable to say whether a woman is or is not a common prostitute within the meaning of the Act. They may morally certain that she is; but if she denies it, proof is difficult and she escapes as the law gives us no definition of the term 'common prostitute' for the guidance of magistrates. ${ }^{46}$

Administrators also grappled with complexities in the heterogenous landscapes characterizing various unmarried groups of women, who were construed of as 'unchaste' in the official mind. This is portrayed in British medical officers' noting certain clandestine categories of workers, who although were not classified as sex-workers in the conventional sense of the term, could also not be typified into the prescriptive categories of Contagious Disease laws for admittance into Lock Hospitals. The dearth of a satisfactory legal, definitional term for various categories of unmarried native women with active sexual agency, thus emerged as a constant source of frustration for British officers, who repeatedly sought to address them through the lens of sexual deviance, crime, and moral turpitude (Mitra, 2020). ${ }^{47}$

In lieu of these complications, an effort to define the native prostitute was determined through the figure of the Devadasi who was an essential part of the socio-cultural landscape of Indian temples. Here, the temple-dancer was constructed as an archetype of backwardness and degradation intrinsic to Hindu religion and culture. She challenged the ideal of the chaste, domesticated wife in Victorian Britain through her practices of religiosity, socio-economic autonomy, and matrilineal inheritance. In defying puritan values of patriarchy, passive sexuality, and conjugal matrimony, she posed a direct threat to the patriarchal order that was being safeguarded in nineteenth century Europe against an emerging feminist consciousness. 
The civilizational metaphor was a central component in representing the Devadasi both as an agent of moral disorder and a social victim (Soneji, 2004). ${ }^{48}$ Additionally, this decreed criminalized caste posed a direct threat to the "health and morality" of the British Empire, which exercised a "humanitarian duty" to "save the lives of these women", "help them contract a regular marriage", alongside "eradicate the moral danger they posed to society. ${ }^{49}$ The social landscape characterizing Devadasi-dedication was orientalized in light of such racialized biopolitics.

Therefore, an ascribed nomenclature of the Devadasi System as 'Prostitution with a religious sanction' allowed for a monolithic presentation of Indian culture as driven primarily by regressive religious traditions and legitimized the imposition of colonial interventions on humanitarian grounds to rescue women. Reform measures such as Contagious Diseases Acts, and Devadasi Prohibition Bills reinforced a taxonomy of racial and gendered classifications in differentiating between the 'good' and 'bad' prostitute. While the former lacked agency in an intrinsically exploitative religiously sanctioned institution and needed protection as subjects of the British Empire, the latter was a spreader of venereal disease, social immorality, and religious backwardness. The two extreme positions of the Devadasi either as a victim of abuse or an immoral profiteer, stripped women of the ability to define their occupations on their own terms, in tandem with precluded their experiential narratives in the making of policy paradigms (Levine, 1993). ${ }^{50}$

Moreover, an international projection of the humanitarian ideals of imperial Britain in abolishing the Devadasi System becomes especially important, in light of India's membership to the League of Nations. While cognizant of the religious sentiments of India as highly sensitive terrain for intervention, compounded by the variegated nature of Devadasi regional practice that evaded binaristic prostitution or trafficking nomenclatures, policy-makers in Britain brought this issue to an worldwide stage to showcase the civilizational functions of its Empire. In a letter dated the $8^{\text {th }}$ of December 1927, Justice Spence advised Viceroy Irwin of the need to direct public opinion in eradicating Devadasi dedication. He considered this attitude of excessive caution justifiable in the face of India's membership to the League of Nations as a part of the British Empire, which subjected the reputation of Great Britain to the scrutiny of the world. ${ }^{51}$ 
Thereby, The Prevention of Dedication Bill introduced in the Madras Legislative Assembly in 1931 declared Devadasi dedication a criminal offense in all territories of British India. ${ }^{52}$ This bill was enacted into nation-wide law upon Indian independence in 1947 and had certain legal particularities. The burden of guilt/proof contrary to principles of English criminal law was to be borne by the accused. It declared Devadasi dedication not only in public temples but also in private sites to be in breach of the penal code. Consequently, the complications of imposing state-specific legislations in line with regional variations of the tradition, led to the passage of nation-wide uniform laws that criminalized these women altogether.

The aforesaid clauses increased the scope of regulations in India to be far more intrusive upon the lives of native women when contrasted with prostitution reform in Britain. The courts were backed by the power of the police and legislators to systematically marginalize deviant subjects. This exemplifies two critical points: Firstly, the description of moral depravity and prostitution is a Eurocentric as well as ethnocentric construction, which implies that such teleologies do not adequately capture historical conditions on ground. Secondly, bourgeoisie Indian elites in the twentieth century internalized colonial judgments and re-appropriated these into nationalist identity (Burton, 1999). ${ }^{53}$

The ascription of criminal traits to non-conforming, subaltern groups like sex-workers, thugs, homosexuals, and transgender subjects in the British Raj, created 'deviant' castes and classes to be penalized, as well as rigidified fluid social practices. The legal, medicinal, and political discourse on prostitution grouped together distinct identities like the courtesan, concubine, temple-dancer and sex-worker into a homogenous category of outcastes, who constituted a threat to British national character (Levine, 2000). ${ }^{54}$ Western genealogies created schisms between the 'normal' and 'deviant' woman, crucial to the maintenance of a hierarchical episteme along civilizing mission theories. In colonial imaginary, the native prostitute was constructed as a discursive subject of regulation to restore the patriarchal orderings of imperial spaces through institutions like courts, hospitals, jails, and schools. The orientalist epistemology of prostitutions laws systematically created a benchmark for the respectable English woman against her licentious Indian counterpart; as Chandra Talpade Mohanty hypothesizes "by which to encode and represent cultural others" (Mohanty, 1991, pp.55). ${ }^{55}$ 
This demonstrates the consequences of colonial regulation in mutating forms of Cultural Capital $^{\text {iii }}$ and 'Gendered Habitus' (Rao, 2009, pp.68-70). ${ }^{\text {iv }}$

Hobsbawn and Ranger's 'Invented Tradition' theory aptly encapsulates the 'invention' of prostitution discourse for Mahari Devadasis. In this, colonial terminologies of Devadasi dedication as religious sanctioned prostitution enabled officials to present the system as an intrinsically exploitative one along a propagandist vein; this allowed for the trafficking of minors alongside prevented women from contracting a regular marriage (Hobsbawm and Ranger, 1983). ${ }^{56}$ The protection of women and children narrative cemented colonial administration along humanitarian grounds. Along Gayatri Chakravorty Spivak's theoretical lens of "White men saving brown women from brown men" hypothesis, presenting Devadasi dedication as an intrinsically barbaric system, allowed the British to justify imperialism as a civilizing mission where they were rescuing native women from their reprehensible practices of a traditional Hindu society (Spivak, 1994). ${ }^{57}$ On this basis, the colonial state could consolidate its administrative hold over the region of Orissa, systematically diminish the hold of the Gajapati Puri Royal Family, and gain access to the pilgrim funds of the temple. However, as this research suggests, colonial discursive epistemes of Mahari Seva (ritual or prayer service) as 'prostitution with a religious sanction' failed to account for complex realities on ground. Thus, the law emerged as a disciplinary panopticon of criminalizing unmarried women and depriving them of their rights and property. In inventing tradition, colonial officials consciously mapped the sexual economy of other regional Devadasi contexts onto Maharis in Puri; this 'false information' altered the knowledge-systems of this temple-complex (Marglin, 2008, pp.214-215). ${ }^{58}$

\footnotetext{
iii In using the terms "Cultural Capital", "Habitus", I invoke Bourdieu's connotation- of how the cultivation of Maharis women was sought along hegemonic lines of a feminine "bourgeoisie respectable" ideal. Maharis have historically rejected this ideal in defining themselves as elite performers dancing for the lord, in exercising their own Cultural Capital.

iv The concept of "Gendered Habitus" refers to the bourgeoise, respectable ideal that women's reform projects in the twentieth century were guided by in the cultivation of a domesticated, moral woman who behaved by upper class and caste cultured ideal. This new habitus sought to regulate the behavior of women and was exclusionary to the vision of gender equality subsequent women's rights movements advocated. Anupama Rao, The Caste Question: Dalits and the Politics of Modern India (Berkeley: University of California Press, 2009).
} 
Furthermore, in what Arjun Appadurai has termed the 'colonial imaginary', issues of bodily disciplining were crucial in establishing a yardstick of civilizational superiority of respectable western femininity against the native sexual deviance. The colonial state had a vital interest in collecting, codifying, and producing information about the people it ruled under the guise of objective knowledge. An orientalist sociology enabled through census surveys, statistics of venereal disease, surveillance tools for prostitutions in bazaar areas, healthcare reports and legal evidence, sought to measure native women's cultural connections to prostitution, in promulgating proper models for feminine behavior (Appadurai, 1993). ${ }^{59}$ The cultivation of female domesticity as a binding social also manifested in the making of colonial education, in the introduction of Home Science as a mandatory subject for women in English-medium schools in India (Hancock, 2001, pp.881-885). ${ }^{60}$ In Foucauldian terms, an 'archeology of knowledge' via colonial hospitals, jails and courts served as panopticons to control the behaviors of racialized others and ossify regimes of disciplining. These sites aimed at to inculcating in women bourgeois virtues of temperance, chastity and domesticity, characteristic of new social forms of disciplining (Foucault, 2013). ${ }^{61}$

Responding to colonial interventions upon religion and native women, in an effort to assert a national identity that was progressive, non-backward and non-superstitious, Indian nationalists rushed to cleanse temples of the stain associated with Devadasi-dedication and re-appropriated colonial nomenclatures. The Hindu Social Reform Association was formed in 1892 by middleclass and upper-caste Hindus with an aim of reforming Hinduism of its so-called 'corrupt' and 'debauch' components. To preserve the reputation of temple-spaces in light of anti-Devadasi laws, nationalists launched the 'Anti-Nautch Movement' towards sanitizing the disrepute associated with temple spaces. ${ }^{62}$ The regulatory framework (convened by both British officials and Indian reformers) affected public opinion in Orissa and sanctioned the 'pure' spaces of temples be cleansed of the 'impure' practices of temple-dancers who had been its historical inhabitants. Under such patriarchal power politics and hegemonic structures, whereas Maharis were previously reputable women in society, they now transitioned to become disenfranchised, illegal and deprave subjects. As argued by Nandy, colonialism perpetuates a certain kind of violence against the colonized subject in seeing the world through the prism of western civilization and an English education. (Nandy, 1988). ${ }^{63}$

Consequently, following the abolition of the Devadasi System in nation-wide regulation laws, Maharis were forbidden from performing religious rituals, alongside extricated from the 
temple's political economy. Furthermore, to preserve the reputation of temple-spaces, Indian nationalists and women's reformers like Dr. Muthulakshmi Reddy appropriated imperial paradigms, whereby the legacy of imperial social customs was normalized and institutionalized in the making of the independent nation-state. (Srinivasan, 1985) ${ }^{64}$ However, the abolition of this custom, instead of improving women's life circumstances, propelled a turn towards clandestine networks of sex-work owing to their rising socio-economic stigmatization in the absence of any concrete measures for skill-development or integration into the market economy.

Following the passage of Devadasi abolition legislations, Maharis were classified as prostitutes in the law and prohibited from performing religious services on a nation-wide basis. Despite performing certain rituals on an intermittent basis, they also stopped receiving a regular maintenance allowance from the Jagannath Temple as recorded in the Temple's Religious Endowments and Expenditure files. ${ }^{65}$ In the framing of the post-colonial nation, the temple was established as a public institution for public worship. Correspondingly, its governance today is regulated by a conjoint bureaucratic body of representatives in line with secular, democratic principles. The colonial legacy of governance via the 'Rule of Records' shaped the administrative dynamics of the temple, which now functions as a giant bureaucracy in itself. Through the above factors, the legacy of the colonial state in perpetuating a Brahminic hegemony continued onto the postcolonial state in the following ways: Firstly, in sanctifying a singular interpretation of Hinduism over its diverse, heteroglot elements; Secondly, in strengthening the hegemonic role of the state apparatus in regulating the behaviors of minority actors that posed a threat to its ideological authority. Thirdly, in instilling a patriarchal structure rooted in a feminine ideal of bourgeoisie respectability that excluded women as temple servants.

Colonial and postcolonial normative laws produced a series of effects for the temple: Legal the transfer of control and governance authority over the temple complex from the Puri Gajapati king to the Orissa State Government; Political - the burgeoning role of the state upon the daily life and religious affairs of the temple which started with the colonial occupation of Orissa and continued post-independence; Economic - the phenomenal wealth of the temple as a defining factor for sustained administrative interventions and the systematic exclusion of Maharis from its funds. These processes bring to light the political, economic, and legal appropriation of the temple. They exemplify how the history of Maharis complicates the 
narrative of the broader Devadasi System owing to the distinctive nature of its development across temporal and spatial frontiers. In embodying mutating, intersectional identities (religion, culture, sexual-economy, class, caste), this case-study provides a complex index into studying how forms of power, dominance, and hegemony function in the production of a certain ideal of exclusionary citizenship.

The above factors illustrate how a homogenization of heteronormative gender identities through taxonomies of 'deviancy' and 'immorality', reinforced and reified the normalization of the patrilineal family as the basis of the independent nation-state's social organization, as well as an embodiment civilizational progress. Subsequently, Devadasi abolition measures in independent India, imbibed colonial nomenclatures in the articulation of a pedagogical ideal for respectable citizenship. This, along with the triumph of global development principles over indigenous contextual practice, has systematically led to a disenfranchisement and decline of subaltern actors in the making of laws pertaining to their rehabilitation or bodily disciplining (Chatterjee, 1989, pp.623-624). ${ }^{66}$

\section{Global Cultural Flows and Movements of Resistance}

In March 2015, the "Last Mahari" in Orissa- Sashimani Devi passed away. Media channels presented this as a defining historical moment- "The Death of the Last Mahari: an age-old community that had died due to colonial and post-colonial patriarchal laws". ${ }^{67}$ The death of Shashimani Devi marks a defining historical moment. While the dance form has been taken up by various dance schools, the inventors of this form have been in gradual decline since in the twentieth century. In 1997, Sashimani gave public performances in Kolkatta under the auspices of the Odissi Vision and Movement Centre. At such public events, she spoke of her adoption process in her formative years whereby older Maharis adopted them towards training them in arts and culture. However, she then recounted how public opinion had turned against the practice in the aftermath of prohibition laws. In conversations with Sashimani, she further elaborated on how a characterization of her erstwhile profession as prostitution or sexual exploitation, epitomized a misrepresentation of complex historical subjectivities. ${ }^{68}$

Though the Orissa State Government has created and supported many dance institutions today, it has not offered financial support to these women, despite several petitions. It has also failed to provide for a safety net to integrate these women into mainstream society or change social 
attitudes that have been shaped by the narratives of the 'immoral, degraded prostitute'. ${ }^{69}$ State welfare programs have further excluded Devadasis from civil society and in a historical paradox, inculcated a turn towards commercial sex-work against a lack of skill development initiatives towards integration in the market economy. The Report of the Special Rapporteur on the Issue of Trafficking of Women and Girls - Commission (Human Rights Mission to Bangladesh, Nepal, and India, 2000) notes some of the problems in the passage of women's reform efforts in these countries: namely "current measures to combat prostitution in India prevent the freedoms and human rights of women", "do not take their economic autonomy and social mobility into account", and "place women at the mercy of men or their families."70

The Global Cultural Flows theory has been instrumental in situating Devadasis within a globalized vocabulary of dance culture and feminist consciousness. This theoretical framework was conceptualized by Arjun Appadurai to delineate how global interconnections through Mediascapes (media outlets shaping ways of understanding the world), Technoscapes (cultural interactions due to the promotion of technology) and Ideoscapes (global flow of ideologies), create powerful knowledge-systems and modes of organization that can help minority actors challenge the top-down discourse of the nation-state (Appadurai, 1990). ${ }^{71}$

Against this backdrop, the death of Sashimani Devi identifies the changing legal, sociocultural, and religious identities of a specific group of women across time and space. This moment brought about a drastic shift in popular culture and public memory at regional, national, and international levels. At the time of an ailing Sashimani Devi, prominent Odissi dancers like Suhag Nalini Das and Methil Devika visited her in Puri and rallied around a revival of the arts of this community. ${ }^{72}$ Post her death, artist Rupashree Mahapatra (who started a school after the Mahari dance-form Rupashree Kalamandir)gave a public statement in 2011 attributing her knowledge of Odissi to the late Sashimani, Parasamani, and Harapriya Devadasis. ${ }^{73}$ This moment even gained widespread global coverage through newspapers like the New York Times and Telegraph $U K{ }^{74}$

Post the extinction of this community, Oriya scholars too have also invoked the power of the Mediascape to showcase the cultural contributions of this group. This has helped inform social positions and attitudes, which have proliferated beyond the nation. Renowned artists like Dinanath Pathy have commented on the patriarchal appropriation of a space that was historically accessible for female agency. ${ }^{75}$ 
In its truest spirit, a dance form cannot be viewed in its artistry in absence of a temple façade more so when each dance posture is a kinetic stance of this cultural art. A modern dancer feels herself quite significant if she gets a chance to dance inside a temple this attitude has led many dancers into the temple's inner halls. After all we should think why a nata mandap (dance hall) exists on the temple premises. Is it not to provide a platform to the dancers to dance and offer their art to the Lord?

-Dinanath Pathy (Presentation at Odisha Lalit Kala Akademi, 2011) ${ }^{76}$

Here, Pathy situates sacred spaces of worship under the democratic scope of 'public access' and 'public utility', by which he critiques the current administrative structure of regulation in the Puri Temple. He evokes Section 15 of the Indian Constitution, which prohibits discrimination on grounds of religion, race, caste, sex, or gender, and guarantees equal access to public spaces. Invoking the temple's basis of public utility, actors today have demarcated its legal basis for public access, in problematizing the exclusion of certain minority groups from it (Devadasis, tribals and caste untouchables).

Drawing on transnational feminist movements, the last two decades have concomitantly witnessed regional resistance movements to advocate for equal citizenship rights of this community. In these protest movements, the term 'Devadasi' has emerged as a unifying term to reclaim a collective past for subaltern communities displaced by similar processes of modernity and patriarchal development. Devadasi identity in recent movements of solidarity constitutes an expansive transnational collective including Odissi professionals, social activists, religious authorities and the mediascape in a rising feminist consciousness. Consequently, Orissa has witnessed a large corpus of indigenous resistance movements, alongside mobilization of local elites to preserve the Mahari form in the temple. These modes of mobilization represent a collective subaltern movement that is directed against hegemonic structures of modernity and neo-liberalism.

The social realities of the contemporary period have thereby allowed for the production of multiple forms of cultural assimilation and knowledge systems. Revisionist scholarship via the works of feminist scholars like Frédérique Apffel-Marglin ${ }^{77}$, Lucinda Ramberg, Davesh Soneji, Amrit Srinivasan and Veena Talwar Oldenberg, has culminated in the writing of a new historiography on subaltern groups like Devadasis (temple-dancers) or Tawaifs (courtesans). ${ }^{78}$ 
This literature stresses on the social renewal of historically marginalized communities, ascertained through the lens of the cultural capital, socio-economic autonomy, female agency and access to the public sphere historically exercised by such matriarchal actors.

Analogously, contemporary Odissi dancers like Kelucharan Mohapatra, Pankaj Charan Das, Sanjukuta Panigrahi, Sonal Mansingh, Madhavi Mudgal, Priyambada Mohanty, and Ileana Citarisi, have been especially vocal in constructing an alternate discourse from the fallen, degraded, and immoral prostitute narrative. In their dance performances at national and global stages, they have stressed upon the 'golden age' of the Mahari dance-ritual as the historical antecedents of a popular, performative culture today appropriated on bourgeoise, respectable stages. In 2012, The Odissi Research Foundation instituted the 'Mahari Award' to be granted exclusively to highly accomplished dancers in this tradition. ${ }^{79}$ In the twenty-first century, the enunciation of a respectable, cultured woman in Oriya identity is innately associated with cultivation in dance. This demonstrates the role of performative culture today in constructing an alternative narrative that departs from exclusionary policy frameworks, alongside being historical agents who inform social attitudes.

In light of the above factors, global culture has provided for a new form of memory when the art form of Devadasis can be transmitted and incorporated beyond national frontiers. Take for example the La Bayadère ballet (Dance of the Temple-Maiden), which has been performed in ballet theatres across Europe and North America. Created by Russian dramatist Sergei Khudekov, this representation revolves around the life of a temple-dancer and incorporates elements of Indian classical dances into ballet techniques. The incorporation of the Devadasi art-form onto an international stage has also been accompanied by its dissemination across a global audience through Indian cinema and Internet channels like Youtube and Soundcloud. This has been instrumental in invoking the multiple identities characterizing Maharis in a departure from conventional marques of religious prostitution or trafficking. Flows of globalization have been pivotal in molding a fluid subaltern identity through the lens of popular culture and collective memory, which has gained new meanings across time. (Breckenridge and Appadurai, 1988). ${ }^{80}$

Activists alike have been instrumental in globalizing the Mahari cause into the wider discourse of third world feminisms. Women's rights NGO's in India like Mahila Abhivrudhi Mattu Samrakshana Samsthe, Durbar Mahila Samanwaya Committee, and Sampada Grameen 
Mahila Sanstha (SANGRAM) have actively campaigned for the dignity of gendered minorities like Devadasis, and lobbied with dance institutes to allow these women to teach their art forms. Take for instance, MASS (Mahila Abhivruddi Mattu Samrakshana Samsthe), which is a selfhelp group in South-India comprising of many ex-Devadasis, which aims to provide an institutional framework of support through access to healthcare, education, and economic emancipation. Through its digital presence of petitions, newsletters, and short films, it has lobbied with international non-profits like Oxfam, alongside promoted Devadasi history in Bollywood films. In 2015, through crowd-funding and digital campaigns, MASS together with Singapore based NGO Milaap, implemented Project Hope that has helped former Devadasis open dance centers and local businesses. ${ }^{81}$ These grassroots organizations propagate equal rights of the Devadasi subject as a legitimate citizen of a democratic nation and critique the governmental protection narrative in passing patriarchal reforms where women are denied agency. The global Devadasi thus has emerged at the site of intersection of indigenous resistance and global interconnectivities. Through documentaries, social media channels and protest slogans, the Mediascape has therein provided a crucial platform for scholars, activists, and women's rights lobbies to broadcast minority voices, through which women can participate in a global culture of feminist consciousness.

Finally, against such emergent grassroots-level movements in the $21^{\text {st }}$ century, it is limiting to study minority voices as isolated cases of subaltern resistance. Rather, one needs to situate them within cosmopolitan formations of globalized cultural flows. What emerges is a collective Mahari identity comprising of dancers, social activists, filmmakers, and journalists who in turn represent this extinct group through the lens of feminist agency alongside community mobilization. Their socio-cultural heritage is no longer restricted to religious spaces in Orissa but occupies the fluid terrains of social media and cultural outlets across the world. The study of such subaltern groups is thus not merely an attempt in reclaiming indigeneity, but also posits the various political tools that marginalized groups use to maneuver through oppressive structures of state-building.

\section{Conclusion}

This paper concludes by examining the significance of the Mahari-Devadasi case-study towards broader themes in gender, women's rights, and humanitarian debates. Firstly, it informs a revisionist historiography through a bottom-up reading of female agency, 
community-solidarity, and resistance against patriarchal kinship networks in pre-colonial, matriarchal societies. Secondly, it provincializes the Eurocentrism in colonial and national women's rights interventions, which critically informed international humanitarian frameworks in the aftermath of Empires. Finally, a granular study of subalternity through Oral Histories, Experiential Accounts and Performative Culture, examines how certain matrilineal communities challenged patriarchal structures through their social, cultural, and quotidian practices. This also incorporates the voices of concomitant gendered minorities in the making of laws, development, and policy paradigms. Through a critical examination of the politics of marginalization for such actors who live on the fringes of civil society, the Mahari case-study thereby contributes towards transnational discourses on subalternity along with women's activist movements in the Global South.

\section{APPENDIX: List of Abbreviations and Explanation of Terms}

IOR = India Office Records (British Library)

$\mathrm{NAI}=$ National Archives of India

OHCA $=$ Orissa High Court Archives

OIOC $=$ Oriental and India Office Collections (British Library)

OSA $=$ Orissa State Archives

\section{Section 372 and 373 of the Indian Penal Code}

Section 372- Any person who dedicates any female under the age of 18 years to the service of any deity or temple with the effect of precluding the marriage of such female, or any person who sells or lets for hire or otherwise disposes of any female to any other female who has been so dedicated shall, until the contrary is proved, be presumed to have disposed of such female with the intent that she shall be used for prostitution.

Section 373- Any person who has been dedicated to the service of any deity or temple with the effect of precluding the marriage of such female, or any person who thereafter buys, hires or otherwise obtains possession of a female under the age of 18 years shall, until the contrary is proved, be presumed to have obtained possession of such female with the intent that she will be used for the purpose of prostitution.

\section{References}


${ }^{1}$ Beauchamp, H.K. and Dubois J. A.(1899). Hindu Manners, Customs, And Ceremonies, $2^{\text {nd }}$ edition, Oxford: Clarendon Press, pp.592-593.

${ }^{2}$ Patil, B.R. (1975). “The Devadasis”, Indian Journal of Social Work 35, no. 4, pp.377-389.

3 "Pankaj Charan Dās (17 Mar. 1925)" in The Oxford Encyclopedia of Music and Dance India, New Delhi, Oxford University Press.

${ }^{4}$ Levine, Philippa (2004). "A Multitude of Unchaste Women: Prostitution in the British Empire", Journal of Women's History, Vol 15, no.4, pp. 159-163.

5 Sreenivas, Mytheli (2011). "Creating Conjugal Subjects: Devadasis and the Politics of Marriage in Colonial Madras Presidency." Feminist Studies, Vol 37, no. 1, pp.63-92.

${ }^{6}$ Apffel-Marglin, Frederique (1995). "Gender and The Unitary Self: Looking for The Subaltern in Coastal Orissa," South Asia Research, Vol 15, no.1, pp.82-93.

${ }^{7}$ Krishnadas, Rajagopal (17 February, 2016). Act against Devadasi system, Supreme Court tells States, The Hindu. Retrieved from: http://www.thehindu.com/news/national/act-againstDevadasi-system-sc-tells-states/article8229560.ece

${ }^{8}$ Chakraborthy, Kakolee (2000). Women as Devadasis: Origin and Growth of The Devadasi Profession, New Delhi: Deep \& Deep Publications.

${ }^{9}$ Chakrabarty, Dipesh (2000). Provincializing Europe: Postcolonial Thought and Historical Difference, Princeton: Princeton University Press.

${ }^{10}$ OSA Public Department (1912), File no. 416, Letter from Rajguru to the Secretary of State for Bengal on the History of Mahari Seva in Puri, pp.1-36.

${ }^{11}$ Prasad, Nanda Chandi (1923). Towards Swaraj: Nationalist Politics and Popular Movements in Orissa, Samaja Newspaper.

12 Sashimani Devi (Last living Mahari Devadasi of Orissa), Interview by Shriya Patnaik. Personal Interview. Puri, August 11, 2014.

${ }^{13}$ Apffel-Marglin, Frederique (1986). Wives of the God-King, The Rituals of The Devadasis of Puri, New Delhi: Oxford University Press.

${ }^{14}$ NAI Progs (1929). No. 1009 - Judicial Files, Home Department, "Resolution passed at a meeting of the Devadasi community regarding the dedication of girls to temples as Eduadanion and Cognate Waller".

${ }^{15}$ Chatterjee, Ratnabali (1993). "Prostitution in Nineteenth Century Bengal: Construction of Class and Gender", Social Scientist, Vol 21, no. 9/11, pp.159-172.

${ }^{16}$ Orizza Gazette No. 205 ( $3^{\text {rd }}$ September, 1956), OSA - Public Files. 
${ }^{17}$ Dinanath Pathy (Former Secretary of the Lalit Kala Academy- National Academy of Arts; Recipient of the Odisha Sahitya Academy Award and Rietberg Award for his research on the arts of Orissa), Interview by Shriya Patnaik. Personal Interview. Bhubaneswar, June 25, 2016.

${ }^{18}$ Levine, Philippa (2003). Prostitution, Race, and Politics: Policing Venereal Disease in the British Empire, New York: Routledge, Pp xv-xvi.

${ }^{19}$ The delegation of Devadasi practices as supernatural, backward, uncivilized, or superstitious can itself be said be an inadequate construct in India's transition to modernity. "The designation of practices as superstitious is a move of modern power. Such a designation does not simply signal the worship of false gods but rather it points to a mistaken apprehension of the world, a wrongness of reason, or a lack of reason. As such, the designation of superstition cannot be taken for granted." Ramberg, Lucinda (2014). Given to the Goddess: South Indian Devadasis and the Sexuality of Religion, Durham: Duke University Press, pp.16.

${ }^{20}$ Kulke, Hermann (1986). The Cult of Jagannath and the Regional Tradition of Orissa, 1st edition, New Delhi: Manohar.

${ }^{21}$ The Pilgrim Tax, originating from Mughal kings was levied on tourists entering Puri, and constituted a large source of income towards temple management. Nancy Gardner Cassels, Religion and Pilgrim Tax under the Company Raj (Maryland: Riverdale Company, 1988).

${ }^{22}$ OSA Temple Board Files no. 2 (May 1806), "Extract of a letter from the Collector of Pilgrim Tax, to the Secretary of Revenue Department".

23 Kulke, Hermann and Dash, Gaganendranath (1982). Orissa: A Comprehensive and Classified Bibliography, Wiesbaden: Steiner.

${ }^{24}$ OSA Jagannath Temple Correspondence (March 1911), “C.R. Metcalfe, Commissioner of the Orissa Division to the Viceroy's Secretary on the dedication of girls in Puri).

${ }^{25}$ OHCA "Petition under article 226 of the Constitution of India, 12 October 1925, Raja Sri Ram Chandra Deb versus State of Orissa", OHCA Judicial Files, no.89.

26 "Letter from T.D. Mackenzie, Secretary to the Viceroy to the Puri District Collector", British Library-India Office Collections, LIMIL/7/13815: Home Department Files, February 13, 1888, no. 320 .

27 Shree Jagannth $\quad$ Temple

http://odisha.gov.in/law/acts/pdf_files/1955/SJTA_1955.pdf

(1955):

${ }^{28}$ Rao, Anupama (2003). Understanding Sirasgaon: Notes Towards Conceptualizing the Role of Law, Caste and Gender in India, in Gender \& Caste, India: Kali for Women.

29 Dash, Gaganendranath (2010). Jagannatha and the Gajapati Kings of Orissa: A Compendium of Late Medieval Texts, New Delhi: Manohar Publishers \& distributors.

${ }^{30}$ Rajguru, S.N. (1960). ('Mukhya Adhyayak'- Chief religious head of Jagannath Temple service), Inscriptions of Orissa, Vol.III, pt.I, Bhubaneswar. 
${ }^{31}$ Apffel-Marglin, Frédérique (2011). Subversive Spiritualties: How Rituals Enact the World New York: Oxford University Press.

${ }^{32}$ Gajapati Maharaj Dibya Singh Deb (Present Puri King, Chairman of Jagannath Temple Managing Committee), Interview by Shriya Patnaik. Personal Interview. Puri, June 13, 2016.

${ }^{33}$ All translations of rituals from Oriya to English are my own. I have preserved the present tense of scriptural text to preserve the original meaning.

${ }^{34}$ The interviews are originally conducted in Oriya. All translations from Oriya to English are done by me.

${ }^{35}$ Rabindranath Pratihari (Jagannath Temple Panda/priest who supervised the daily rituals of Maharis), Interview by Shriya Patnaik. Personal Interview. Puri, July 2, 2016.

${ }^{36}$ Oriya Chronicles describing the historical events of Odisha and the legends of Jagannath.

${ }^{37}$ Khera, Krishan Lal (1996). Index to History of Dharmas Astra By Pandurang Vaman Kane: Comprehensive Guide to Hindu Rites and Rituals, India: Munshiram Manoharlal Publishers.

${ }^{38}$ Louis Dumont also discusses how notions of purity and pollution are a defining feature of Hindu religious practices and social customs. Sebaks in the Jagannath Temple have historically abided by these norms. In a hierarchical ordering of social groups, relations outside of caste, religion and especially with foreigners was strictly disallowed. This disputes the colonial claim of these woman in engaging with prostitution as spreaders of disease. Their social interactions were highly regulated along lines of religious custom. Refer to Louis Dumont 'Homo Hierarchicus'. Social Science Information 8, no. 2 (1969): pp.69-87.

39 OIOC File No. L/MIL/7/13834, "Surgeon-General W. A. Thomson, Principal Medical Officer: "British Troops to Secretary, Government of India, Military Department, August 13, $1890 "$.

40 Hyam, Ronald (1990). Empire and Sexuality: The British Experience, Manchester: Manchester University Press.

${ }^{41}$ Ballhatchet, Kenneth (1980). Race, Sex, and Class under the Raj: Imperial Attitudes and Policies and Their Critics, 1793-1905, London: Weidenfeld and Nicolson.

42 Arnold, David (1993). Colonizing the Body: State Medicine and Epidemic Disease in Nineteenth-century India, Berkeley: University of California Press.

${ }^{43}$ Smith, F. B.(1971). Ethics and Disease in the Later Nineteenth Century: The Contagious Diseases Acts, Historical Studies 15, no. 57, pp.118-135.

${ }^{44}$ Levine, Philippa (1994). Venereal Disease, Prostitution, and the Politics of Empire: The Case of British India. Journal of the History of Sexuality Vol 4, no. 4, pp.579-602.

${ }^{45}$ Collingham, E.M. (2001). Imperial Bodies: The Physical Experience of the Raj, C. 18001947. Cambridge: Polity Press, pp.14. 
${ }^{46}$ IOR File P/1338, Home Proceedings of the Government of India, Sanitary Department for 1879, "Horace A. Cockorell, Secretary to Government of Bengal to Secretary of Government of India Home Department, 11 July", (1878).

${ }^{47}$ Mitra, Durba (2020). Indian Sex Life: Sexuality and the Colonial Origins of Modern Social Thought, Princeton: Princeton University Press.

${ }^{48}$ Soneji, Davesh (2004). Living History, Performing Memory: Devadāsī Women in TeluguSpeaking South India, Dance Research Journal Vol 36, no. 2, pp.30-49.

49 NAI: Legislative Files-General Branch, Progs. No. 230 (1927), "Enquiry from local governments of Bombay, Madras, Mysore and Oudh of whether a system of organized traffic in women and children exists in their provinces".

${ }^{50}$ Levine, Philippa (1993). Women and Prostitution: Metaphor, Reality, History, Canadian Journal of History, 28: pp.482-491.

${ }^{51}$ NAI File No. 28III-General, Legislative Proceedings (1924) "League of Nations enquiry into traffic in women and children in India, draft Devadasi Bill”.

${ }^{52}$ NAI File No. 97/30 Legislative Assembly Records (1930) "A Bill in the Madras High Court to prevent the dedication of women to service in Hindu Temples as Devadasis".

${ }^{53}$ Burton, Antoinette (1999). Gender, Sexuality and Colonial Modernities, London: Routledge.

${ }^{54}$ Levine, Philippa (2000). Orientalist Sociology and the Creation of Colonial Sexualities. Feminist Review Vol 65: pp.5-21.

${ }^{55}$ Mohanty, Chandra Talpade (1991). Under Western Eyes: Feminist Scholarship and Colonial Discourses in Chandra Talpade Mohanty, Ann Russo and Lourdes Torres (eds.) Third World Women and the Politics of Feminism, Bloomington: Indiana University Press).

${ }^{56}$ Hobsbawm, E.J. and Ranger, T. O. (1983). The Invention of Tradition. Cambridge:

Cambridge University Press.

${ }^{57}$ Spivak, Gayatri Chakravorty (1994). Can the subaltern speak? in Patrick Williams \& Laura Chrisman (eds), Colonial Discourse and Post-Colonial Theory (Hemel Hempstead: Harvester Wheatsheaf, , pp.90-105.

${ }^{58}$ Apffel-Marglin, Frederique (2008). Rhythms of Life: Enacting the World with the Goddesses of Orissa New Delhi: Oxford University Press.

59 Appadurai, Arjun (1993). Number in the colonial imagination, in Orientalism and the Postcolonial Predicament: Perspectives on South Asia, Carol Breckenridge and Peter van der Veer (eds), Philadelphia: University of Pennsylvania Press.

${ }^{60}$ Hancock, Mary (2001). Home Science and The Nationalization of Domesticity in Colonial India", Modern Asian Studies, Vol 35: pp.881-885.

${ }^{61}$ Foucault, Michel (2013). Archaeology of Knowledge, Hoboken: Taylor and Francis. 
${ }^{62}$ NAI: Home Department, File 820 (1922), “Dr. H.S. Gour's Bill to Amend the Indian Penal Code and the Code of Criminal Procedure for the Purpose of criminalizing the Devadasi System".

${ }^{63}$ Nandy, Ashis (1988). The Intimate Enemy: Loss and Recovery of Self under Colonialism New Delhi: Oxford University Press.

${ }^{64}$ Srinivasan, Amrit (1985). Reform and Revival: The Devadasi and Her Dance, Economic and Political Weekly Vol 20, no. 44: pp.1869-1876.

65 "Collector of Tax, to Secretary to the Commissioner for the Affairs of the Jagannath Temple", 2 March 1879, OSA: Jagannath Religious Endowments and Expenditure Files, Part I.

${ }^{66}$ Chatterjee, Partha (1989). Colonialism, Nationalism, And Colonialized Women: The Contest in India, American Ethnologist Vol 16, no. 4: pp.622-633.

${ }^{67}$ Devika, Methil (November 14, 2012). Of dancers wedded to the Lord, The Hindu. Retrieved from: http://www.thehindu.com/todays-paper/tp-national/tp-kerala/of-dancers-wedded-to-the lord/article4094470.ece

${ }^{68}$ Ray, Baijayanti (December 17, 1997). Brides of The Lord, The Asian Age, Calcutta.

${ }^{69}$ Petition of the Gajapati Maharaj, S.N. Rajguru and Jagannath Mukti Mandap sebak to revive Mahari Seva, Kadimbini (August 3, 1978), pp.62-63.

70 "Report of the Special Rapporteur on the Issue of Trafficking of Women and GirlsCommission on Human Rights Mission to Bangladesh, Nepal and India (November 2000)": NAI: Home Department Files 16.3.

71 Appadurai, Arjun (1990). Disjuncture and Difference in The Global Cultural Economy, Theory, Culture \& Society Vol 7, no. 2-3: pp.295-310.

${ }^{72}$ Devika, Methil (November 14, 2012). Of dancers wedded to the Lord: The Last Mahari, The Hindu. Retrieved from: http://www.thehindu.com/todays-paper/tp-national/tp-kerala/ofdancers-wedded-to-the lord/article4094470.ece

73“'Sashimani Devi, Temple Dancer - Obituary",The Telegraph UK, April 14, 2015. Retrieved from: http://www.telegraph.co.uk/news/obituaries/11535593/Sashimani-Devi-temple-dancerobituary.html

${ }^{74}$ Barry, Ellen (March 23, 2015). Sashimani Devi, Last of India's Jagannath Temple Dancers, Dies at 92, The New York Times. Retrieved from: http://www.nytimes.com/2015/03/24/world/asia/sashimani-devi-last-of-indias-jagannathtemple-ritual-dancers-dies-at-92.html

75 Nivedita Mohanty (author of Oriya Nationalism and Imagining Orissa, significant texts on Orissa history and culture), Interview by Shriya Patnaik. Personal Interview. Bhubaneswar, June 30, 2016. 
${ }^{76}$ Dinanath Pathy "Why Deny the Lord- A history of the Mahari tradition in the Jagannath Temple”, Presentation at Odisha Lalit Kala Akademi-Bhubaneswar (May 9, 2011).

${ }^{77}$ Frédérique Apffel-Marglin's works on religion and Devadasi ritual in the Jagannath Temple are particularly pertinent to this trajectory of research. Refer to Frédérique ApffelMarglin, Wives of the God-King: The Rituals of the Devadasis of Puri (New Delhi: Oxford University Press, 1986); Frederique Apffel Marglin, "Redefining the Body", in Divine passions: The Social Construction of Emotion in India, edited by Owen M. Lynch (Berkeley: University of California Press, 1990); Frederique Apffel-Marglin, Rhythms of Life: Enacting the World with the Goddesses of Orissa (New Delhi: Oxford University Press, 2008).

${ }^{78}$ Refer to Lucinda Ramberg, Given to the Goddess: South Indian Devadasis and the Sexuality of Religion (Durham: Duke University Press, 2014); Davesh Soneji, "Living History, Performing Memory: Devadāsī Women in Telugu-Speaking South India", Dance Research Journal 36, no. 2 (2004): pp.30-49; Davesh Soneji, 'Śiva's Courtesans: Religion, Rhetoric, and Self-Representation in Early Twentieth-Century Writing by Devadāsīs", International Journal of Hindu Studies 14, no. 1 (2010): pp.31-70; Davesh Soneji, "The Powers of Polyglossia: Marathi Kīrtan, Multilingualism, and the Making of a South Indian Devotional Tradition", International Journal of Hindu Studies 17, no. 3 (2013): pp.339-369; Davesh Soneji, Unfinished Gestures: Devadasis, Memory, and Modernity in South India (Chicago: University of Chicago Press, 2012); Amrit Srinivasan, "Reform and Revival: The Devadasi and her Dance", Economic and Political Weekly 44, no. 2 (1985): pp.1869-1876; Amrit Srinivasan, "The Hindu Temple-Dancer: Prostitute or Nun?" Cambridge Anthropology 8, no. 1 (1983): pp.73-99; Veena Talwar Oldenberg, "Lifestyle as Resistance: The Case of the Courtesans of Lucknow, India”, Feminist Studies 16, no. 2 (1990): pp.259-287; Veena Talwar Oldenberg The Making of Colonial Lucknow, 1856-1877 (Princeton: Princeton University Press, 1992).

79 "Maharis Award to be Presented to Minati Pradhan", The Hindu, March 11, 2012. http://www.thehindu.com/todays-paper/tp-national/tp-otherstates/article2983988.ece

${ }^{80}$ Breckenridge, Carol and Appadurai, Arjun (1988). Why Public Culture? Public Culture Vol 1, no. 1: pp.5-9.

${ }^{81}$ Mahila Abhivrudhi Mattu Samrakshana Samsthe - MASS: https://www.massbelgaum.org/ 